\title{
Verso una musealizzazione della forma
}

\author{
Leonardo Baglioni \\ Marta Salvatore \\ Graziano Mario Valenti
}

Abstract

La geometria descrittiva è stata da sempre parte integrante del processo progettuale nelle diverse fasi di cui esso si compone. A questa scienza è demandato il controllo delle proprietà delle linee e superfici che definiscono la forma e ne è affidata la comunicazione attraverso il disegno. La geometria descrittiva, intesa come qualità regolatrice del processo metodologico e generativo del progetto architettonico, sembra essere entrata in crisi con l'avvento del nuovo millennio in seguito all'introduzione delle tecnologie digitali e alla possibilità di generare la forma attraverso algoritmi che ne automatizzano i processi. In questo contesto viene proposta una riflessione sul ruolo di questa disciplina, sulla sua attualità e su come partecipi all'interno del processo generativo nel suo complesso. Queste riflessioni hanno portato all'esigenza di esplicitare le ragioni della forma, oggi come nel passato.Viene presentata dunque una sperimentazione orientata alla realizzazione di un museo della forma, concepito come un laboratorio virtuale e fisico in cui verificare e sperimentare le relazioni che legano fra loro geometria, forma e progetto. Questa idea di museo si sviluppa intorno all'idea di modello, inteso non soltanto come risultato ultimo della costruzione geometrica della forma ma come processo generativo da cui questa ha avuto origine, divenendo strumento di misura dell'impatto che le proprietà geometriche hanno avuto e continuano ad avere nella forma.

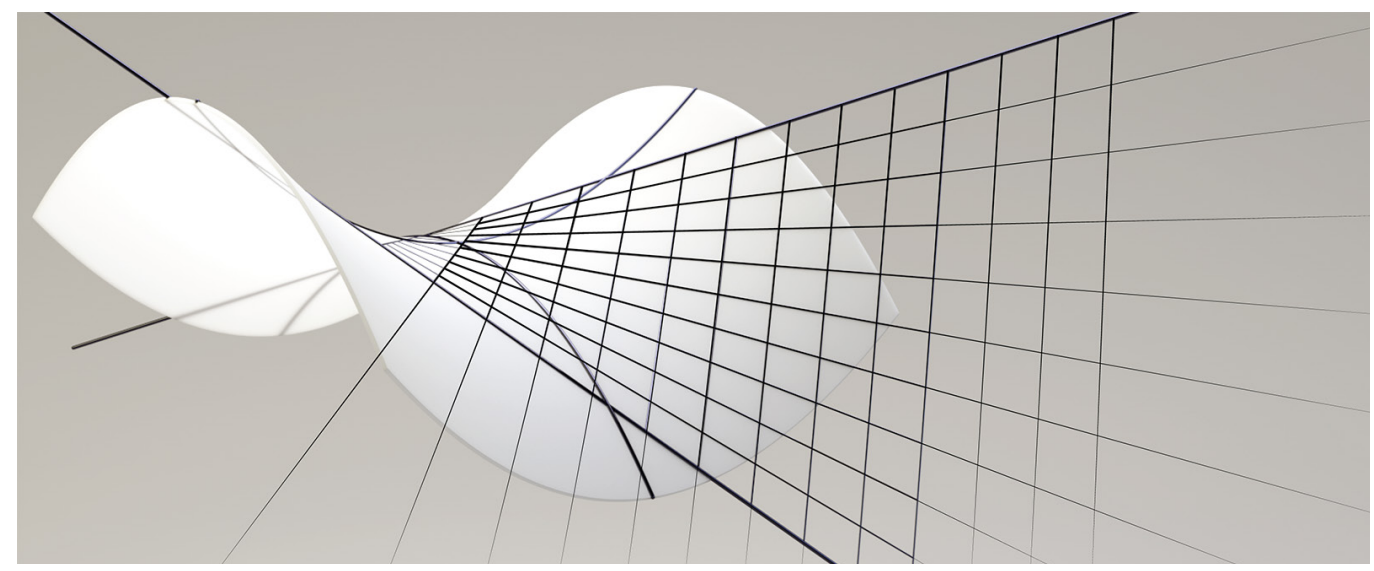




\section{Geometria, forma, progetto}

Nella storia del progetto di architettura la geometria è sempre stata parte integrante del processo creativo, dalle fasi preliminari di definizione morfologica dell'opera a quelle finali della sua realizzazione. Lo è stata in maniera esplicita, negli anni in cui il pensiero geometrico ha assunto un'identità condivisa, lo è stata in maniera implicita sin dall'antichità, quando veniva sapientemente praticata in modo intuitivo e sperimentale. Alla geometria, in particolare alla geometria descrittiva, è demandata infatti la conoscenza della forma in termini di proprietà delle linee e delle superfici di cui questa si compone, e ancora le è affidata la sua comunicazione attraverso il disegno. Queste due anime della geometria sono strettamente legate fra loro e hanno da sempre contribuito alla maturazione progressiva del progetto [I]. L'evoluzione delle teorie geometriche, la conseguente derivazione di proprietà sempre nuove delle figure, l'affinamento progressivo dei metodi della rappresentazione, l'introduzione di tecnologie e materiali innovativi e, non ultime, le esigenze dettate da rinnovati processi produttivi, hanno portato a un incremento progressivo della complessità del repertorio delle forme sperimentabili nel progetto, segnando in maniera determinante alcune delle tappe fondamentali della sperimentazione morfologica in architettura.

La storia ci ha tramandato un uso sapiente e consolidato della geometria descrittiva nei processi progettuali, intesa come qualità regolatrice del processo metodologico generativo della forma. Questo ruolo, che appare chiaro fino alla fine del secolo scorso, sembra essere entrato in crisi con l'avvento del nuovo millennio. La diffusione delle ormai consolidate tecnologie digitali, la possibilità di generare la forma attraverso algoritmi che ne automatizzano i processi e la ottimizzano rispetto a preposte condizioni di vincolo, alimentano oggi nei progettisti, l'idea di poter operare in assoluta libertà. Lo scenario è entusiasmante e foriero di potenziale innovativo, ma sarebbe intellettualmente riduttivo pensare di poter operare senza una metodologia logica e critica capace di realizzare un ponte di continuità con la storia della geometria e il suo ruolo nel progetto.

Oggi infatti, più che in passato, la sperimentazione sulla forma riceve input da diversi ambiti della conoscenza, rendendo il progetto di architettura un organismo sempre più complesso, anche solo da un punto di vista strettamente morfologico. In questo contesto, ci siamo chiesti quale debba essere il ruolo della geometria descrittiva, e se sia legittimo pensare che questa scienza possa essere considerata accessoria o addirittura estranea al processo generativo nel suo complesso.

Per mettere a fuoco la questione abbiamo cercato di ordinarla analizzando il modo e le fasi in cui la geometria interviene ed è intervenuta nei processi progettuali, proponendo una possibile classificazione degli approcci generativi da cui la forma trae origine. Come abbiamo già osservato, la geometria può partecipare ex ante al processo progettuale, in fase ideativa,

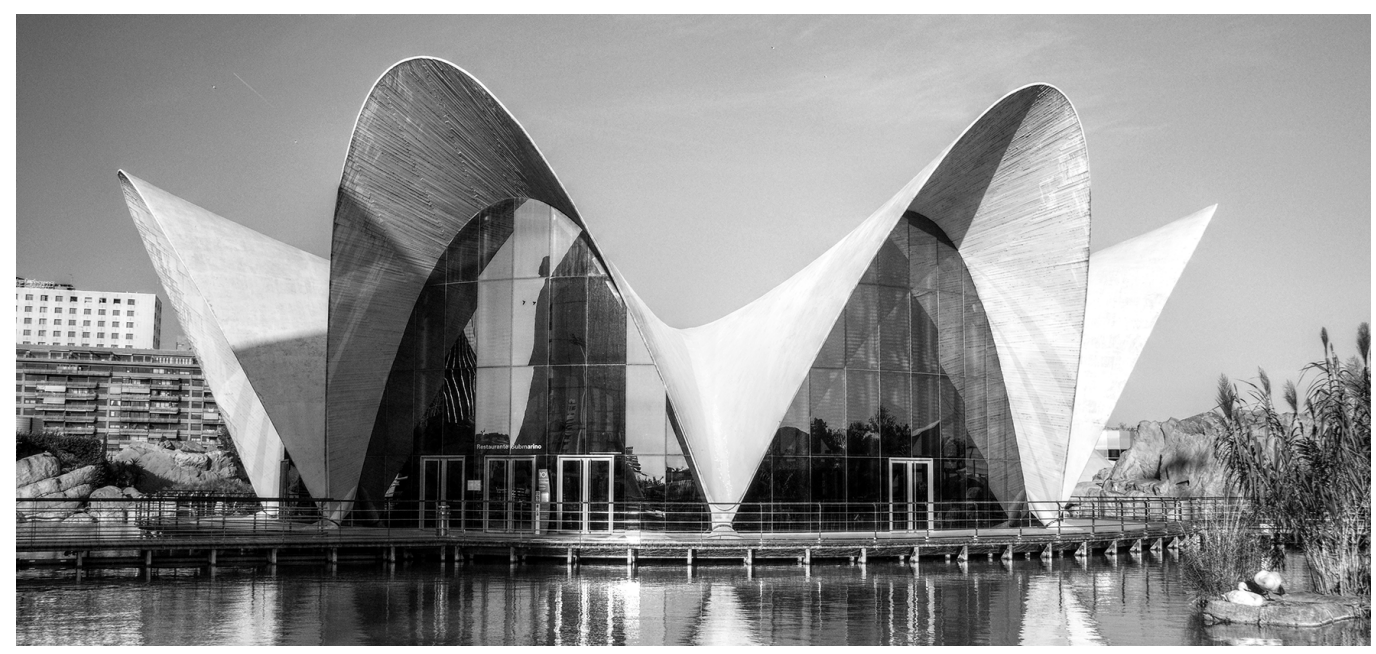


ponendosi come matrice formale. Possiamo far rientrare in questa classe le opere in cui la geometria è veicolo di espressività della forma, come accade nei progetti di Pier Luigi Nervi, Felix Candela o Santiago Calatrava, per citarne soltanto alcuni senza andare troppo indietro nel tempo, dove l'estetica della forma è espressione della sintesi magistrale del binomio geometria-struttura (figg. I, 2). Ma la geometria può intervenire anche in itinere, come risultato di una serie di condizioni di vincolo predeterminate. Per descrivere meglio questa idea possiamo riferirci alle sperimentazioni condotte da Otto Frei sulle superfici minime negli anni Settanta, la cui geometria deriva dalla disposizione dei telai, così come al processo generativo alla base del ponte sul Basento realizzato negli stessi anni da Sergio Musmeci, che opera con le medesime superfici, o anche alle sperimentazioni condotte da Antoni Gaudi sulle catenarie (fig. 3). Ma rientrano in questa classe, se così la si può definire, anche alcuni progetti generati per via parametrica, in cui la forma risponde all'esigenza di ottimizzazione di alcuni prerequisiti. Ė questo il caso dei numerosi progetti di stadi presentati da Luigi Moretti alla XII Triennale di Milano nel 1960, oggi un'icona della progettazione protoparametrica, in cui la forma deriva dal calcolo degli angoli di visuale dei singoli spettatori [Imperiale 20।8, pp. 7I -82]. Particolarmente significativo a questo riguardo è ancora il caso della ricerca ESO (Evolutionary Structural Optimization), sugli algoritmi evoluzionistici applicati al progetto, i cui esiti possono essere apprezzati in diverse opere realizzate, come ad esempio il Qatar National Convention Center di Doha di Arata Isozaki inaugurato nel 20 I I, in cui la forma è il risultato delle caratteristiche strutturali dell'edificio [2] (fig. 4). La geometria infine può intervenire ex post, quando una forma libera, concepita alla maniera di uno scultore, deve essere razionalizzata per esigenze di carattere costruttivo, orientate all'ottimizzazione dei costi e dei processi di realizzazione. Ė il caso di alcune architetture di Frank O. Gehry, come ad esempio il Marta Herford Museum del 2005, nel quale il processo di ottimizzazione della forma ha ridotto l'involucro esterno a porzioni di superfici sviluppabili. Nei processi di ottimizzazione ex post non interviene tuttavia necessariamente la geometria. Spesso, in particolare nelle opere di carattere 'monumentale', è il mondo della produzione a risolvere il problema ponendosi come 'ottimizzatore' della forma, con le conseguenze economiche che questo comporta. Esemplificativo in tal senso è il progetto della Fondation Louis Vuitton inaugurata a Parigi nel 2014, anch'essa di Gehry, il cui involucro è stato realizzato attraverso

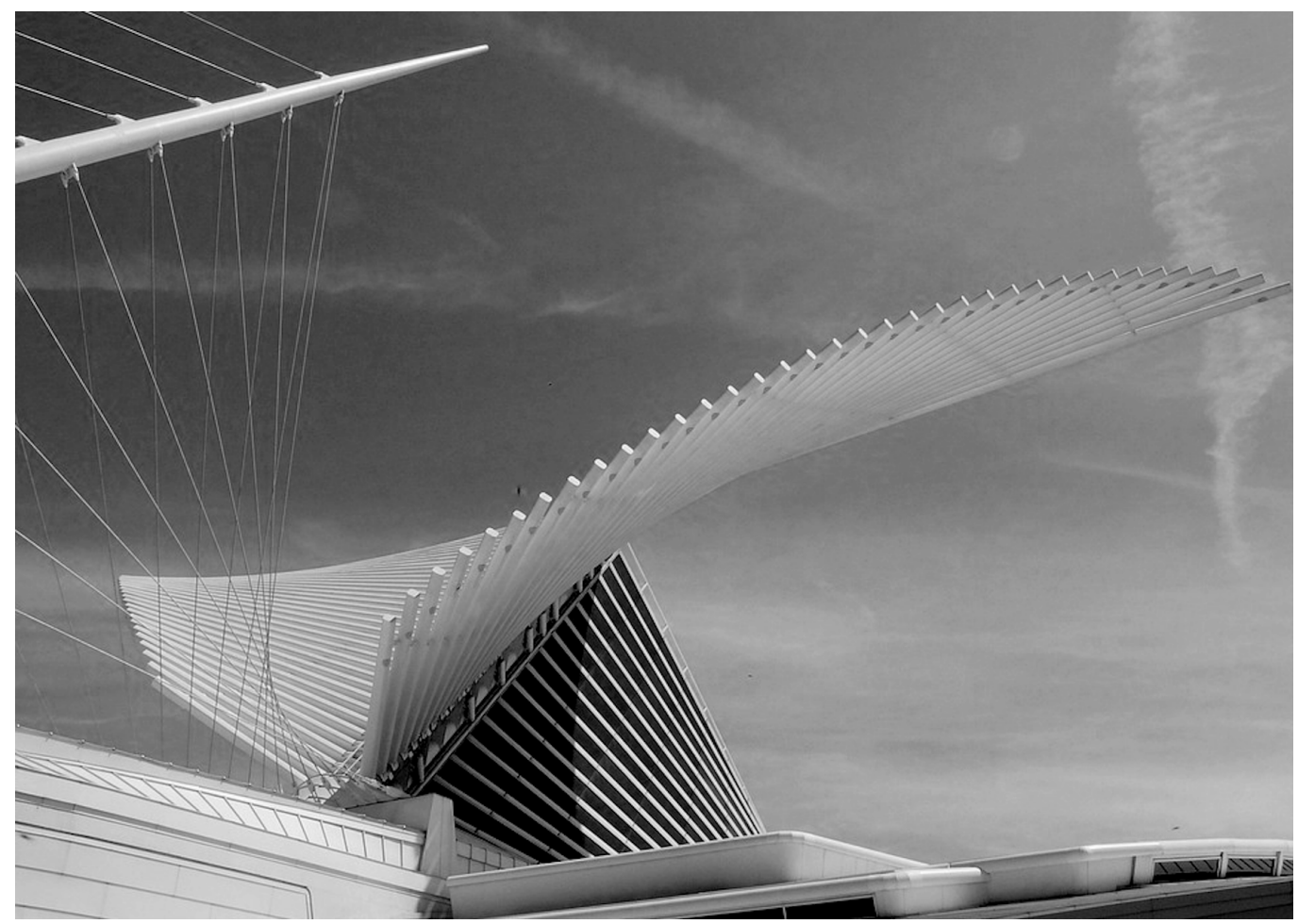


la produzione di più di 16000 tessere speciali realizzate con tecnologie all'avanguardia nella produzione di stampi adattivi [Vaudeville 2013, pp.279-284] (fig. 5).

Questi pochi riferimenti devono essere letti come un'occasione per rilanciare un dibattito intorno alle ragioni geometriche della forma, che riteniamo essere oggi un elemento fondamentale di riflessione critica e punto centrale di sviluppo della ricerca in architettura, per le sue ricadute in ambito didattico e professionale. Per mantenere viva l'attenzione su questa questione è necessario che sia tramandato alle generazioni future il valore della forma. Siamo convinti che la maniera più efficace di trasmettere questo valore sia la sperimentazione attraverso la fruizione diretta dei modelli che la rappresentano, delle loro relazioni reciproche e delle loro mutue trasformazioni. Queste convinzioni sono il fondamento di una ricerca in essere orientata alla realizzazione di un museo della forma, concepito come un laboratorio virtuale e fisico in cui esplicitare e sperimentare, in modo dinamico e interattivo, le relazioni che legano fra loro geometria, forma e progetto.

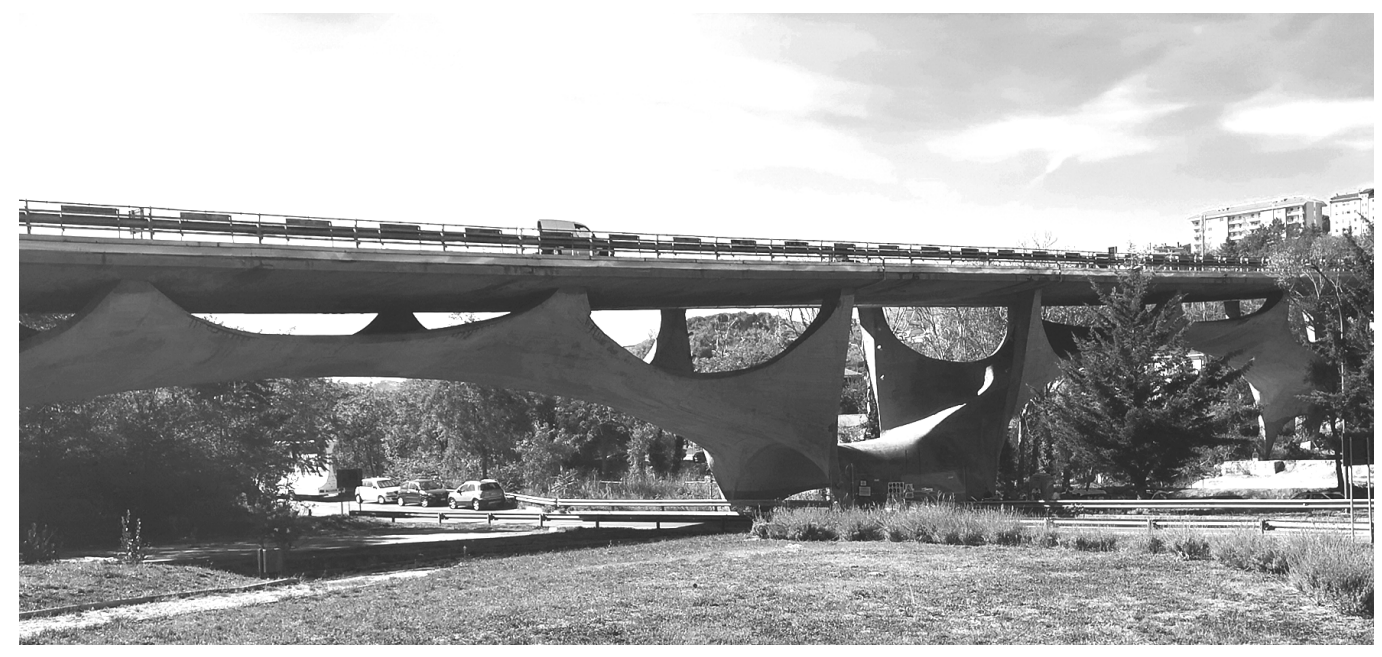

\section{Verso un'idea di musealizzazione}

L'idea di uno spazio che possa esplicitare le proprietà notevoli delle linee e delle superfici analizzando come queste si possano riversare nella forma costruita dell'architettura, vede dunque la sua più efficace concretizzazione in un museo della forma. Uno spazio mutevole e in continua evoluzione connotato da un forte carattere laboratoriale nel quale sperimentare e verificare le specificità delle entità geometriche, esposte attraverso modelli fisici e virtuali, in un sistema ciclico che trasformi e integri gli uni negli altri.

È evidente il legame con le collezioni dei modelli matematici realizzati in Europa tra la seconda metà dell'Ottocento e i primi anni del Novecento, oggetto di un'operazione culturale di forte impatto che vide coinvolte le più grandi menti del pensiero scientifico del tempo. Queste esposizioni erano finalizzate a "far vedere proprietà notevoli riguardanti il tema di ricerca su cui si investigava e a mostrare alcuni risultati che progressivamente si conseguivano in diversi settori delle matematiche 'pure' e 'applicate': Geometria descrittiva e proiettiva, Geometria analitica, Geometria algebrica" [Palladino 2009, p. 3 I]. I modelli matematici delle numerose collezioni erano realizzati con materiali di diverso tipo come gesso, ottone, fili metallici e, nonostante il loro carattere artigianale, rispondevano efficacemente all'esigenza di mostrare e dimostrare attraverso un linguaggio visuale analogico le caratteristiche notevoli delle entità rappresentate (fig. 6). Veniva così favorito l'approccio intuitivo alla geometria che, in accordo con gli insegnamenti hilbertiani, "portava a una chiara percezione degli oggetti considerati e a una rappresentazione concreta delle loro relazioni reciproche" [Hilbert 1932, p.VII]. 
Queste forme di comunicazione visiva della matematica sono state il punto di partenza per la definizione di un'idea espositiva, articolata intorno alla realizzazione di 'modelli'. Inseriti in un contesto di tipo museologico, questi 'oggetti scientifici', che illustrano la forma, devono essere offerti alla fruizione del pubblico in modo da permettere la comprensione profonda della loro natura. Per facilitare questa lettura critica riteniamo necessario rivisitare il valore semantico di questi modelli, che devono mostrare non soltanto il risultato ultimo della loro costruzione geometrica ma l'intero processo generativo da cui hanno avuto origine, le loro proprietà e l'impatto che tali proprietà hanno avuto e continuano ad avere nella forma costruita. Ma non solo; è inoltre necessario ridisegnare, alla maniera di un museologo, un sistema di relazioni in grado di connettere fra loro gli oggetti esposti, ordire la trama delle transizioni fra gli uni e gli altri e stabilire le modalità di interazione fra gli oggetti e i fruitori. Riteniamo che questo sistema di connessioni debba operare per mezzo dei linguaggi visivi della geometria descrittiva, che non sono di natura simbolica, ma sintetica. Questi linguaggi, attraverso cui il metodo sintetico indaga e comunica la forma, si fondano sul carattere 'costruttivo' di questa scienza. Gino Loria nei primi anni del Novecento sosteneva che la costruzione è dimostrazione esistenziale della forma, e mai come oggi, nello spazio virtuale di un computer, questa affermazione appare di attualità [Loria 1935, pp. 77-83]. L'idea di costruzione esplicita il suo significato se si intende la 'geometria dell'estensione' come la scienza che tratta in termini astratti procedimenti ripetibili che possono essere riprodotti nella realtà fisica.

Fig. 4. II Qatar National Convention Center di Doha progettato da Arata Isozaki, inaugurato nel 2011 (credits UNCTAD).

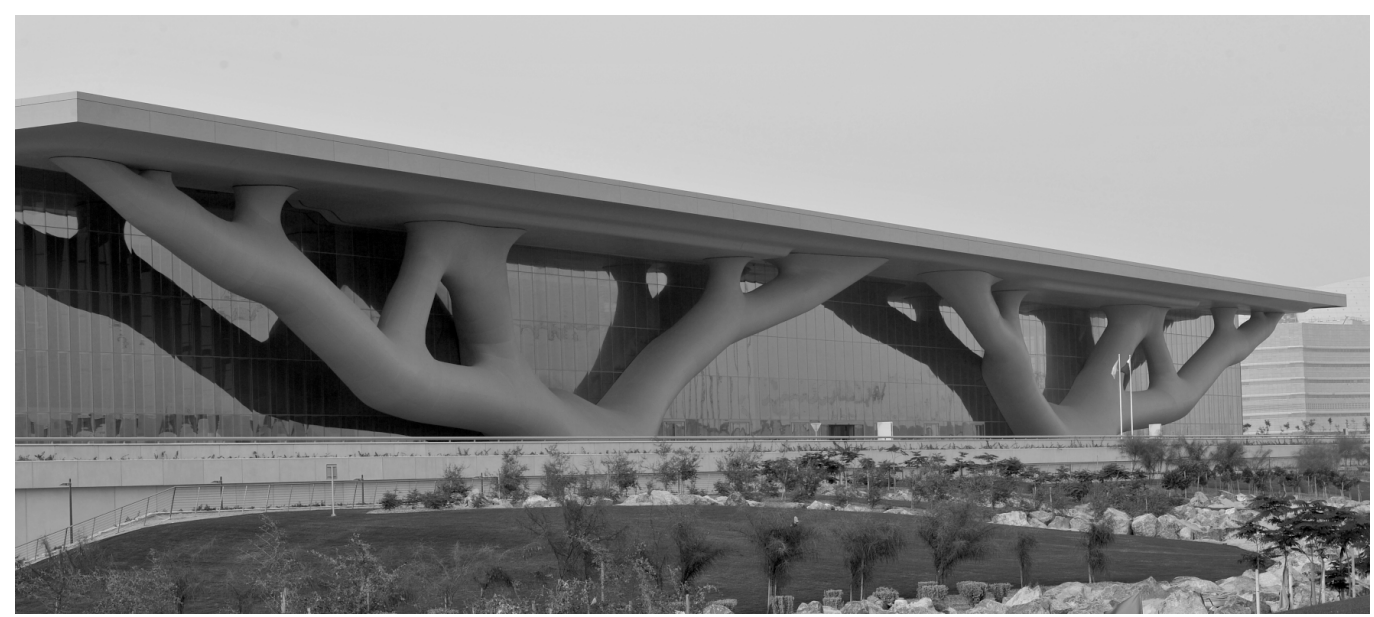

Il concetto di 'modello', nella tradizione architettonica, esprime un connubio fra arte, scienza e tecnica, descrivendo l'insieme delle operazioni atte a rappresentare la forma intesa nella sua più ampia accezione, realizzata e progettata. II modello, statico nella sua concezione analogica, con l'avvento della rappresentazione digitale ha cambiato paradigma. Se i modelli analogici, sia grafici che fisici, comunicavano un aspetto alla volta dell'oggetto rappresentato, oggi i modelli digitali costituiscono a tutti gli effetti una piattaforma di esplorazione dinamica e immersiva della forma. Uno stesso modello digitale può descrivere infatti aspetti diversi, declinandosi di volta in volta in modo diverso, per soddisfare finalità diverse. Questa adattabilità trova riscontro in ambiente digitale, attraverso modalità di fruizione statica o dinamica della forma, favorendo l'esplorazione immersiva e l'interoperabilità fra diversi ambiti di sperimentazione. Allo stesso tempo questa trova riscontro nello spazio reale, dove il modello, prototipato, acquisisce forma fisica, favorendo l'interazione diretta con la forma. L'idea di modello che struttura questo spazio espositivo è dunque quella di un 'oggetto scientifico' dinamico e mutevole che si inserisce in un sistema organico di relazioni capaci di riprodurre ed esplicitare processi generativi. 
Fig. 5. Le lastre in fibrocemento della Louis Vuitton Foundation progettata da Frank O. Gehry nel 2014

Fig. 6. II catalogo di Martin Shilling di modelli matematici per la visualizzazione di oggetti geometrici

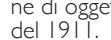

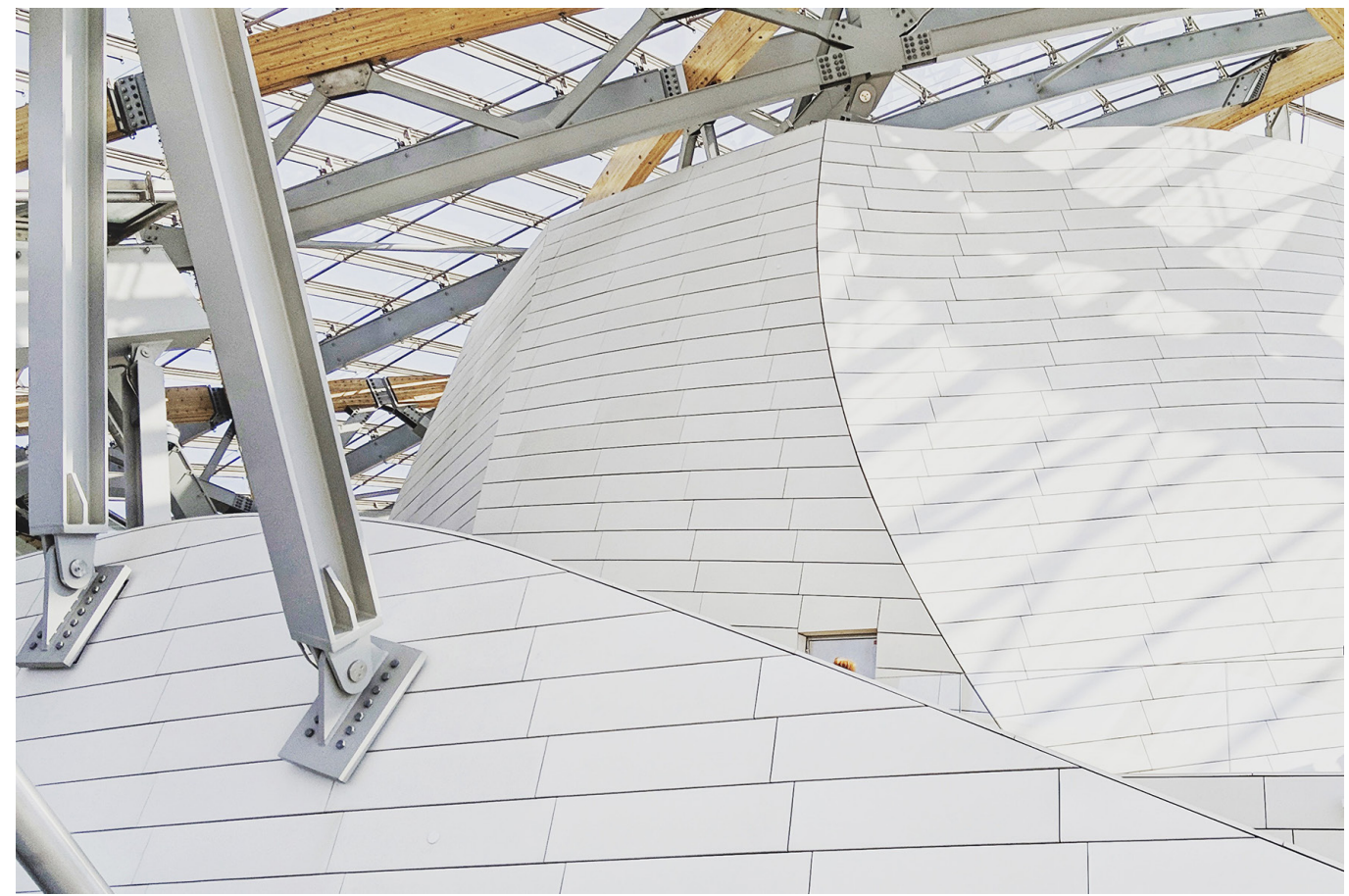

In quest'ottica, sono state condotte diverse esperienze prototipali, sviluppate in ambito di ricerca e in ambito didattico, che riteniamo significative rispetto alla classificazione dei processi generativi a cui si è fatto cenno nel paragrafo precedente. Nel caso delle superfici luogo geometrico ad esempio, la geometria interviene nelle fasi ideative del processo progettuale e, poiché matrice formale, esige una rappresentazione continua della forma. Se pensiamo all'uso del paraboloide iperbolico nei progetti di Felix Candela, possiamo osservare come le proprietà di questa superficie, la sua genesi, la simmetria, le sue sezioni piane, siano elementi che strutturano la morfologia del progetto e ne consentano il controllo delle parti [3] (fig. 7). Stesso discorso per le architetture di Santiago Calatrava, fra le quali risultano di particolare interesse quelle cinetiche, in cui il movimento dipende strettamente dalla genesi geometrica delle superfici impiegate [4]. In questi casi la rappresentazione parametrica del progetto appare lo strumento più efficace per esprimere la cinematica della forma (fig. 8). Diverso il caso delle architetture in cui la geometria interviene in itinere, e quindi è il risultato di alcune condizioni di vincolo, secondo un approccio di tipo finding form. In questi casi il processo prevale sulla forma finita e la rappresentazione ne ripercorre l'algoritmo generativo, come illustra il caso della rilettura delle geometrie del ponte sul Basento della figura 9.
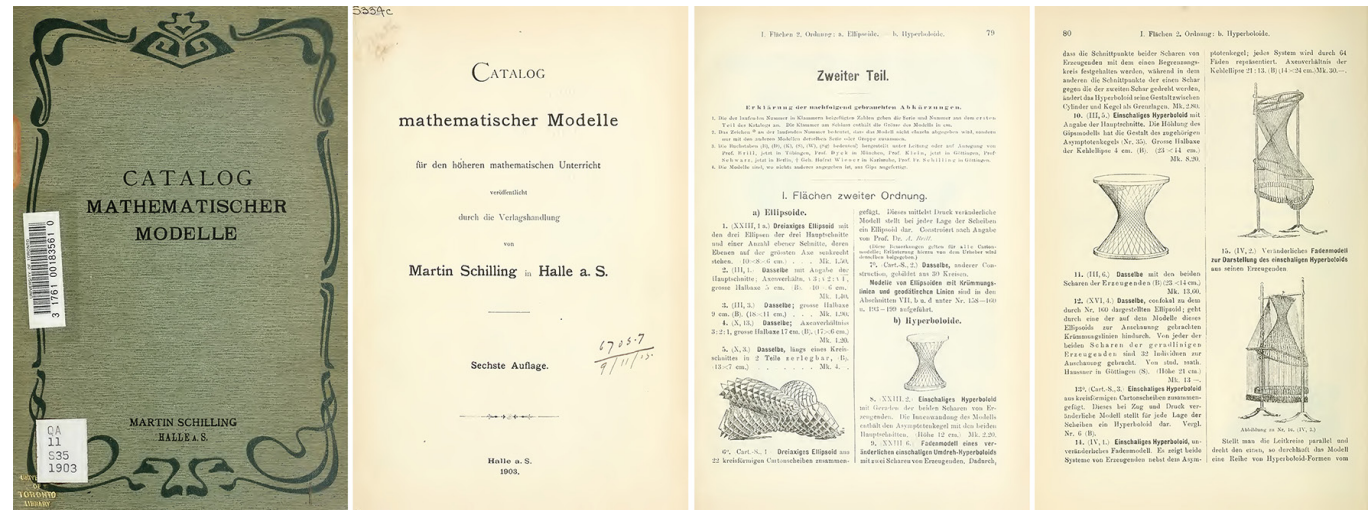
Fig. 7. Diverse aggregazioni del paraboloide iper-

bolico in alcuni progetti

di Felix Candela (mode
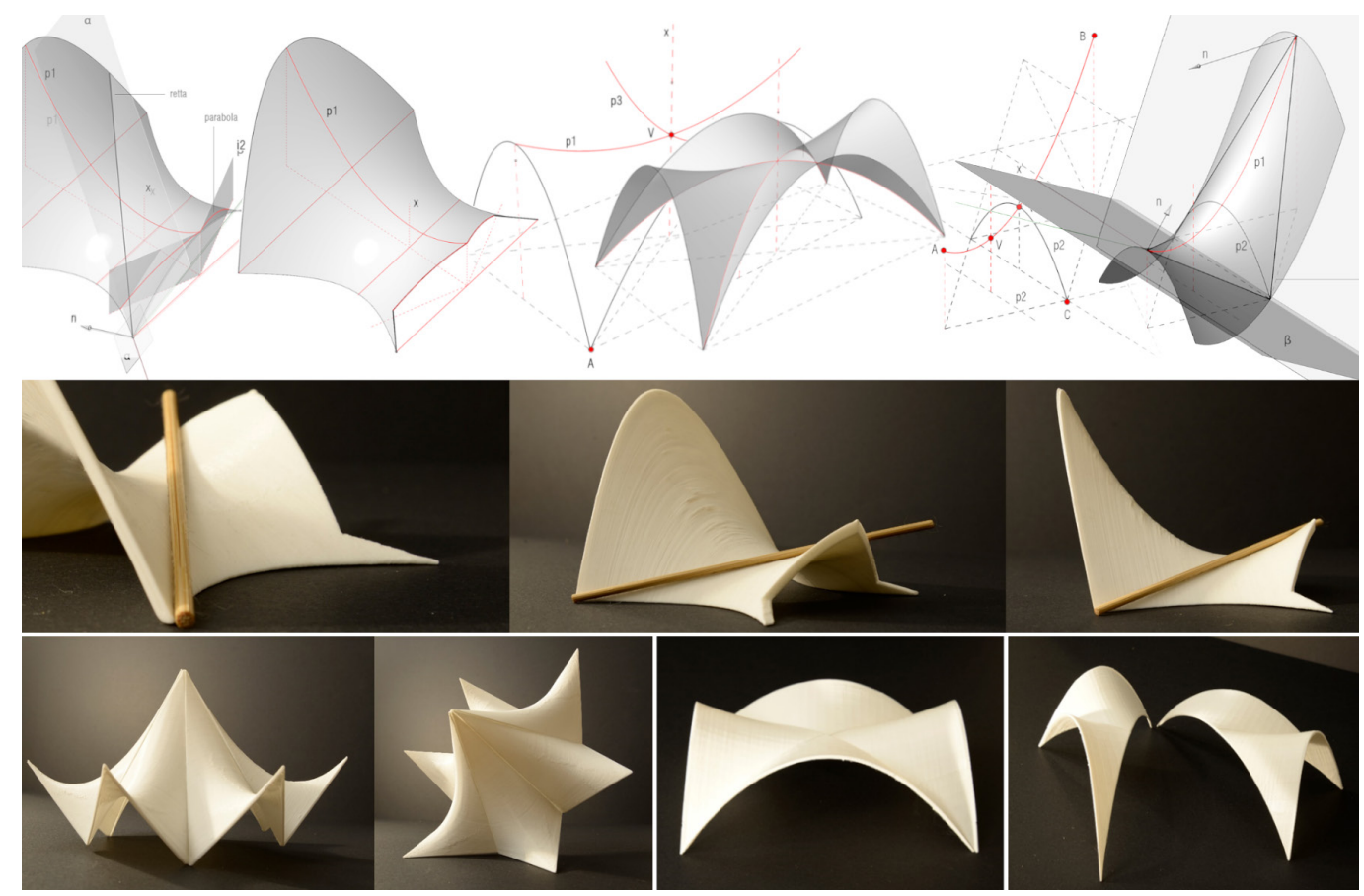

Fig. 8. Modelli parametrici per la rilettura di alcune architetture cinetiche
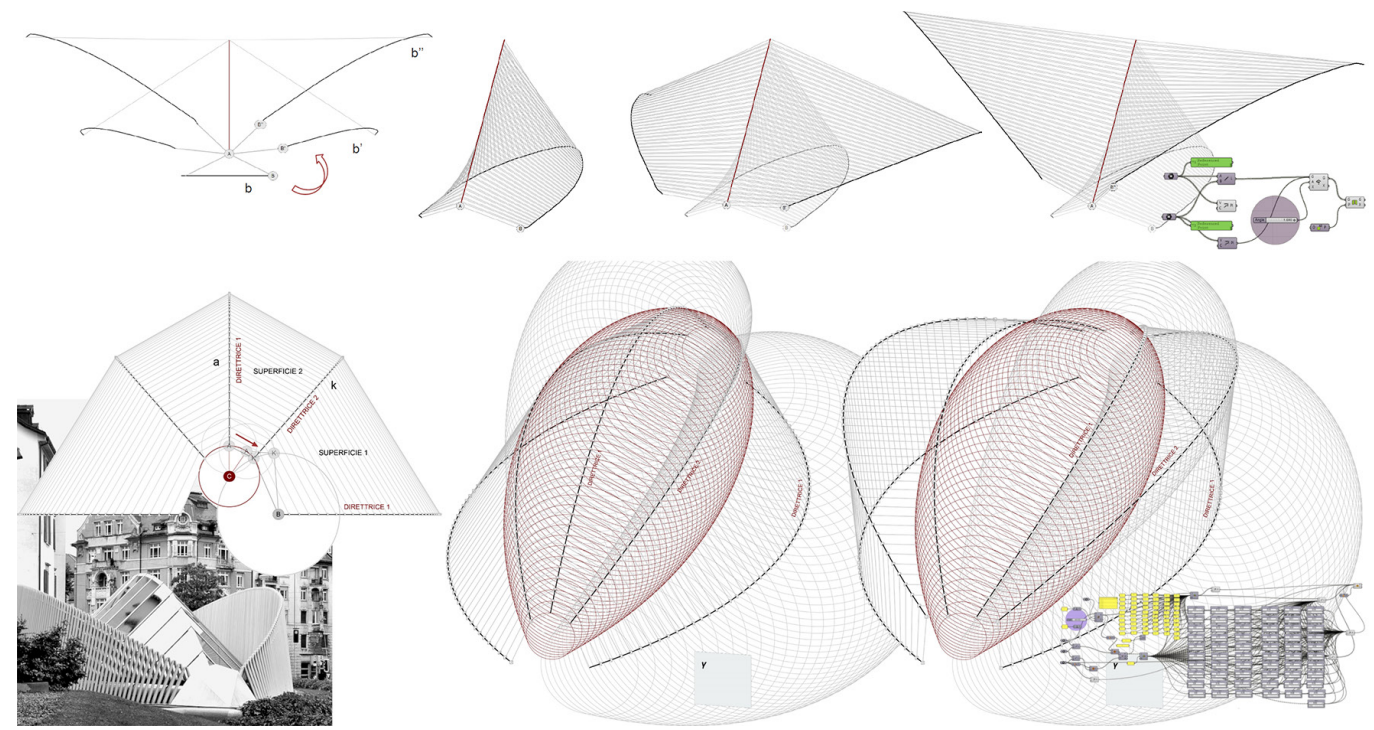
Fig. 9. La ricerca della forma condotta con gli trumenti digitali per la rilettura di catenarie (in lto) e delle superfici minime (in basso)

Fig. 10. Discretizzazione di una superficie libera continua per mezzo di composta di elementi quadrilateri piani

(PQ mesh).
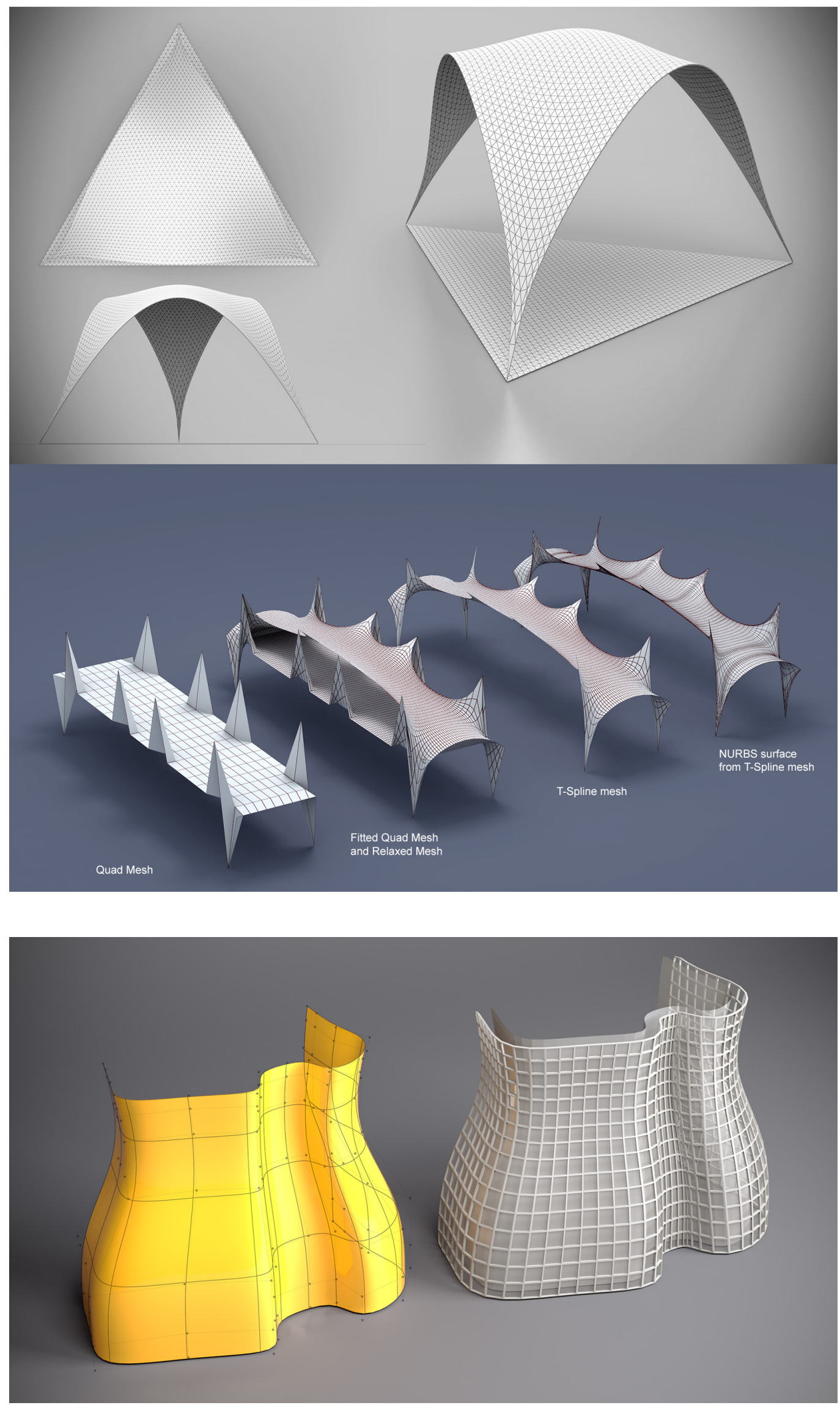
Per fare riferimento a un ulteriore caso esemplificativo del modus operandi che sostiene questa idea di musealizzazione, consideriamo il caso in cui la geometria interviene ex post. Allo scopo è particolarmente interessante fare riferimento alle applicazioni sperimentali in ambito architettonico delle PQ-mesh (Planar quadrilateral mesh) [Pottmann 2007, p. 677] che, derivate dalle linee di curvatura di una superficie continua, la discretizzano in elementi piani quadrilateri (fig. I0).

\section{Prospettive di sviluppo}

Nel 1966 giungeva sugli schermi delle sale cinematografiche Fantastic Voyage di Richard Fleischer. II film narra di un avventuroso viaggio all'interno del corpo umano, condotto da un equipaggio a bordo di un sottomarino entrambi miniaturizzati. Ancora oggi, a distanza di oltre cinquanta anni, se pur assuefatti ai prodotti delle più moderne tecnologie di CGI, non è difficile comprendere l'impatto comunicativo che quelle immagini ebbero sugli spettatori e come questo sia servito a far conoscere a un vastissimo ed eterogeneo pubblico, la forma che ci appartiene ma ignoravamo. Un risultato incredibile, che non fu raggiunto grazie ai primordiali effetti speciali, quanto piuttosto sollecitando l'immaginario onirico dello spettatore attraverso il cambio di scala e il passaggio fra la vista "da fuori a quella da dentro".

Proprio in questa dualità percettiva, caratteristica del passaggio dalla piccola alla grande scala, così come dal reale al virtuale e ancora dal contenuto al contenitore, pensiamo possa trovare compimento l'obiettivo comunicativo e formativo di un museo della forma; uno spazio ove l'esperienza della conoscenza avviene in un continuum fra modello di architettura e architettura stessa: parimenti esperienziali, parimenti comunicativi, parimenti formativi (fig. I I).

Fig. I I. La Galleria della Matematica nel British Museum progettata da Zaha Hadid.

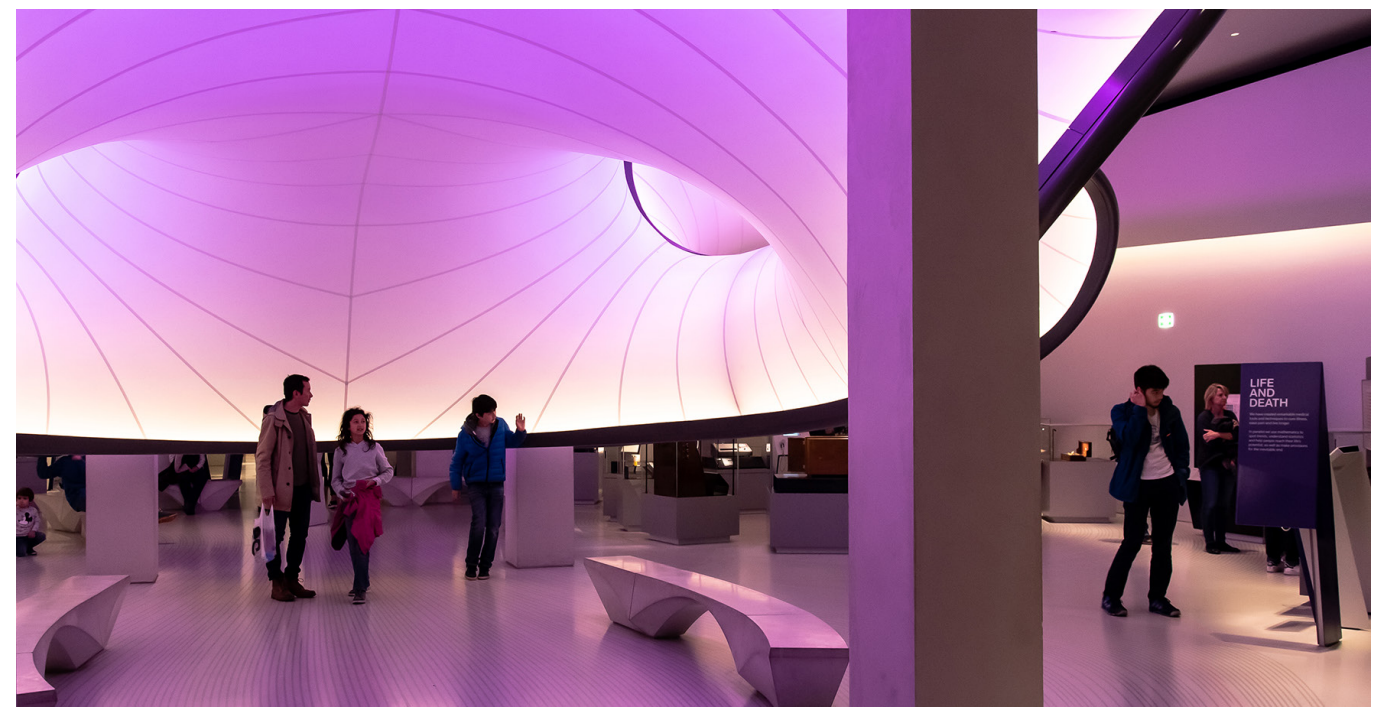

Note

[I] Come il disegno favorisce la sperimentazione sulla forma, così questa esige strumenti di rappresentazione sempre più efficaci e all'avanguardia per la sua comunicazione, alimentando un circolo virtuoso che ha arricchito con costanza, nel tempo, il repertorio della forma nell'arte del progettare.

[2] Insieme al progetto per la stazione TAV di Firenze del 2002 di Isozaki, il Qatar National Convention Center è fra gli esempi più significativi di edifici che utilizzano algoritmi generativi di ottimizzazione topologica di tipo evolutivo esplicitando le potenzialità del metodo ESO [Capruso, Martire 2015, p. I06].

[3] Osserviamo in particolare come porzioni diverse della stessa superficie, sezionate secondo curve notevoli diano luogo nella loro aggregazione a un repertorio di progetti morfologicamente molto diversi.

[4] Molte delle architetture cinetiche di Santiago Calatrava impiegano superfici rigate a piano direttore; le aste che appartengono a ognuna delle superfici che compongono l'architettura ruotano su piani che hanno la medesima giacitura dei piani direttori descrivendo, nel moto, archi di circonferenza. 


\section{Riferimenti bibliografici}

Capurso Gianluca, Martire Francesca (20I5). "Buongiorno, signori. lo sono un elaboratore ELEA 9000". Calcolo automatico e progettazione strutturale. In Martire Francesca (a cura di). Storia dell'ingegneria strutturale in Italia - SIXXI 2. Roma: Gangemi Editore, pp. 98- I I0.

Di Palma Wilma (1999). Un Museo della Matematica: Utopia o realtà possibile. In Di Palma Wilma (a cura di). I racconti di Numeria. Guida alle collezioni di modelli matematici del Comune di Roma. Roma: Argos, I0 pp.

Hilbert David, Cohn-Vossen Stefan (1972). Geometria Intuitiva. (Traduzione di Adolfo Verson). Torino: Bollati Boringhieri. (Ed. orig. Anschauliche Geometrie Einfachste Grundbegriffe der Topologie. Berlin: Springer-Verlag, 1932).

Imperiale Alicia (20 I 8). An 'Other' Aesthetic: Moretti's Parametric Architecture. In LOG, 44, pp. 7I-82

Loria Gino (1935). Metodi matematici. Milano: Hoepli.

Palladino Nicla, Palladino Franco (2008). I modelli matematici costruiti per l'insegnamento delle matematiche superiori pure e applicate. In Ratio Mathematica, 19, pp. 31-88.

Pottmann Helmut et al. (2007). Architectural Geometry. Exton: Bentley Institute Press.

Vaudeville Bernard et al. (2013). How Irregular Geometry and Industrial Process Come Together: A Case Study of the "Fondation Louis Vuitton Pour la Creation", Paris. In Hesselgren Lars et al. (eds.). Advances in Architectural Geometry 20 I 2. Wien: Springer-Verlag, pp. 343

\section{Autori}

Leonardo Baglioni, Sapienza Università di Roma, leonardo.baglioni@uniromal.it

Marta Salvatore, Sapienza Università di Roma, marta.salvatore@uniromal.it,

Graziano Mario Valenti, Sapienza Università di Roma, grazianomario.valenti@uniromal it

Per citare questo capitolo: Baglioni Leonardo, Salvatore Marta, Valenti Graziano Mario (2020). Verso una musealizzazione della forma/Towards a Musealization of Shape. In Arena A., Arena M., Brandolino R.G., Colistra D., Ginex G., Mediati D., Nucifora S., Raffa P. (a cura di). Connettere. Un disegno per annodare e tessere. Atti del $42^{\circ}$ Convegno Internazionale dei Docenti delle Discipline della Rappresentazione/Connecting. Drawing for weaving relationships. Proceedings of the 42th International Conference of Representation Disciplines Teachers. Milano: FrancoAngeli, pp. 47-66. 


\title{
Towards a Musealization of Shape
}

\author{
Leonardo Baglioni \\ Marta Salvatore \\ Graziano Mario Valenti
}

Abstract

Descriptive geometry has always been an integral part of the design process in the different phases of which it is made. This science is entrusted with the knowledge of the properties of the lines and surfaces that make up the form and with communication through drawing. Descriptive geometry, here understood as the regulatory quality of the methodological and generative process of the architectural project, seems to have suffered a crisis with the advent of the new millennium with the introduction of digital technologies and the possibility of generating form through algorithms that automate its processes. In this context, a reflection is proposed regarding the role of this discipline, on its relevance and on how it participates within the generative process. These reflections have lead to the need to explain the reasons of form, today as in the past. Hence, an experimentation oriented to the creation of a museum of form is therefore presented, conceived as a virtual and physical laboratory wherein to verify and test the relationships that link geometry, form and project among themselves. This idea of a museum develops around the idea of model, intended not only as the ultimate result of a geometric construction of form but as a generative process from which it is originated, becoming an instrument for measuring the impact that the geometric properties have had and continue to have in the constructed form.

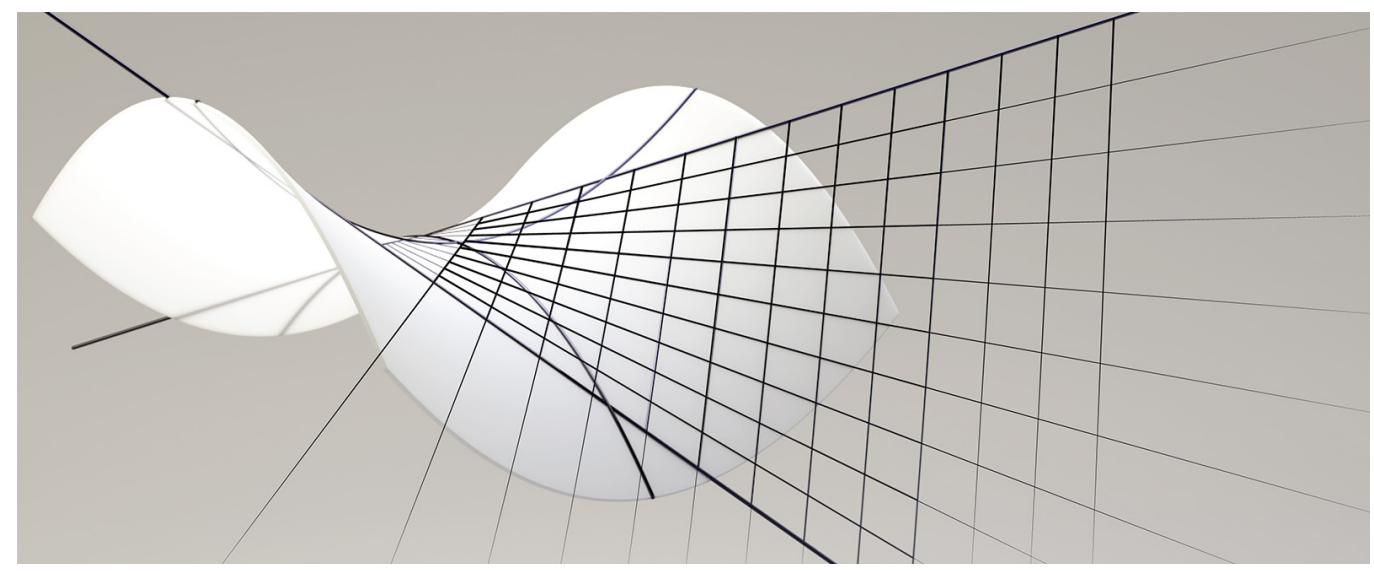




\section{Geometry, shape, design}

In the history of architectural design geometry has always been an integral part of the creative process, from the preliminary stages of morphological work definition to the final stages of its realization. This was explicitly so in the years when geometrical thinking assumed a clear and shared identity and was implicit from ancient times, when it was wisely practiced in an intuitive and experimental way. Geometry, in particular descriptive geometry, focuses on the knowledge of shape, namely of the properties of the lines and surfaces of which it consists and manifests itself through design. These two aspects of geometry are closely linked and have always contributed to the progressive development of the design process [I].The evolution of geometric theories, the consequent derivation of constantly new properties of the figures, the refinement of representation methods, the introduction of innovative technologies and materials and, not least, the exigencies dictated by renewed productive processes, have led to a progressive increase in the complexity of the repertoire of experimentable shapes in design. All these factors mark, in a decisive way, some of the fundamental stages of morphological experimentation in architecture.

History has handed down to us a wise and consolidated use of descriptive geometry in design processes, intended as a regulatory quality of the generative methodological process of shape. This role, which appears clear until the end of the last century, seems to be 'in crisis' with the advent of the new millennium. The diffusion of already consolidated digital technologies, the possibility of generating shape through algorithms that automate the processes and optimize it according to certain constraints, now encourage designers to operate in absolute freedom. The scenario is exciting and harbinger of innovative potential, but it would be intellectually reductive to think of operating without a logical and critical methodology, capable of establishing a bridge of continuity with the history of geometry and its role in the project.

Today, more than in the past, experimentation with shape receives input from different areas of knowledge, making architectural design an increasingly complex organism, even if only from a strictly morphological point of view. In this context, we asked ourselves what the role of descriptive geometry should be today, and whether it is legitimate to think that this discipline can be considered an accessory or possibly extraneous to the generative process as a whole.

In order to focus on this question, we tried to arrange things by analyzing the manner and the phases within which geometry operates and operated in design processes, proposing a possible classification of the generative approaches from which shape originates. As we have already observed, geometry can participate ex ante in the design process and in the conceptual phase as a formal matrix. In this class we can include the works in which geometry

Fig. I.The Oceanographic

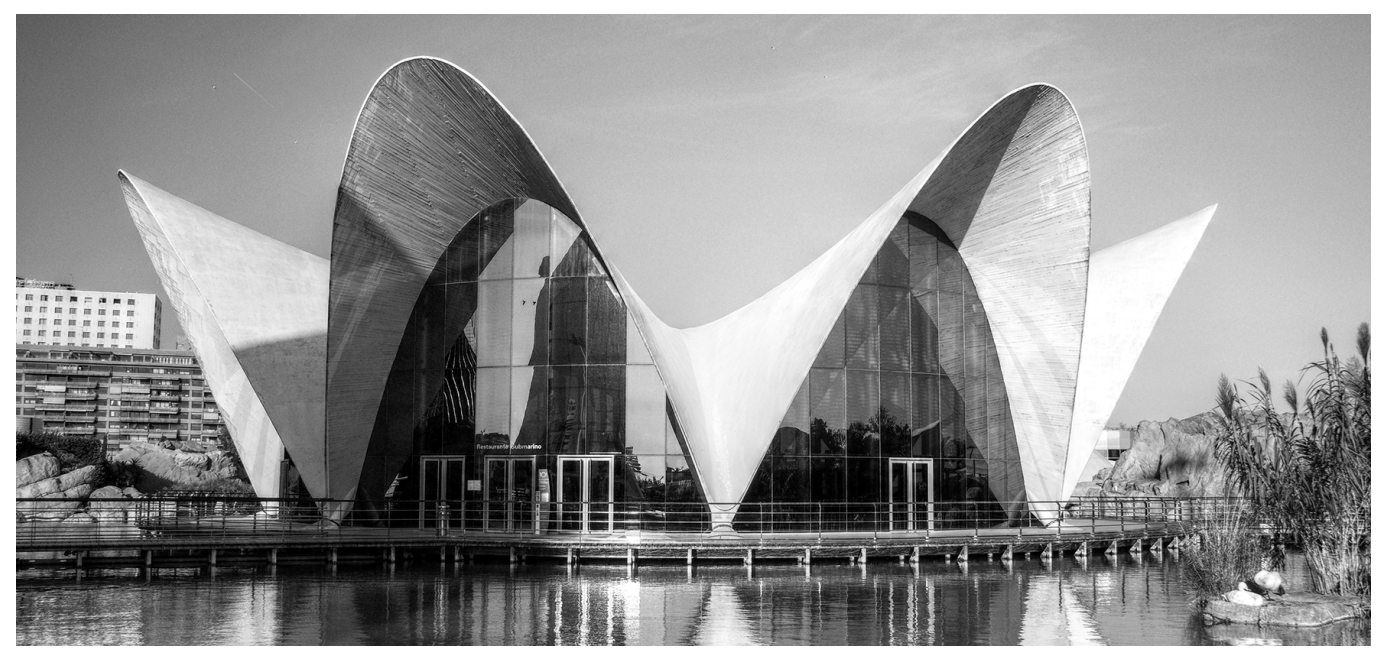


is a vehicle for the expressiveness of shape. This occurs in the projects of Pier Luigi Nervi, Felix Candela or Santiago Calatrava, to name only a few without going too far back in time, where the esthetics of shape is an expression of the masterful synthesis of the binomial geometry-structure (figs. I, 2). But geometry can also intervene in itinere, as a result of a series of predetermined constraint conditions. To better describe this idea we can refer to the experiments conducted by Otto Frei on minimal surfaces in the Seventies, whose geometry derives from the arrangement of frames. We can also refer to the generative process at the basis of the Basento bridge realized in the same years by Sergio Musmeci, who works with the same surfaces, or also to the experimentations conducted by Antoni Gaudi on the catenary curves (fig. 3). However, some parametrically generated designs, if we can so define them, are also part of this class, where the form satisfies the need for optimizing certain prerequisites. This is the case regarding numerous stadium designs presented by Luigi Moretti at the XII Milan Triennale in 1960, today an icon of protoparametric design, in which shape derives from a calculation of the viewing angles of individual spectators [Imperiale 20 I 8, pp. 7I-82]. Particularly significant in this regard is the case of the ESO (Evolutionary Structural Optimization) research on evolutionary algorithms applied to the project, whose results can be appreciated in several completed works, such as the Qatar National Convention Center in Doha by Arata Isozaki inaugurated in $20 \mathrm{II}$, where the shape is the result of the structural characteristics of the building [2] (fig. 4). Finally, geometry can intervene ex post when a free form, conceived as a sculptor would, must be rationalized considering constructive exigencies and oriented towards the optimization of costs and execution. This is the case of some of Frank O. Gehry's architectures, such as the Marta Herford Museum opened in 2005, where the process of shape optimization reduced the outer shell to the portions of developable surfaces. However, geometry is not necessarily involved in ex post optimization processes. Often, particularly in works of a 'monumental' nature, the productive world solves the problem by acting as a shape 'optimizer', with the economic consequences that this produces. Exemplary in this sense is Gehry's Louis Vuitton Foundation project, inaugurated in Paris in 2014, whose casing was realized through the production of more than 16000 special tiles, made with advanced technology in the production of adaptive molds [Vaudeville 20।3, pp. 279-284] (fig. 5).

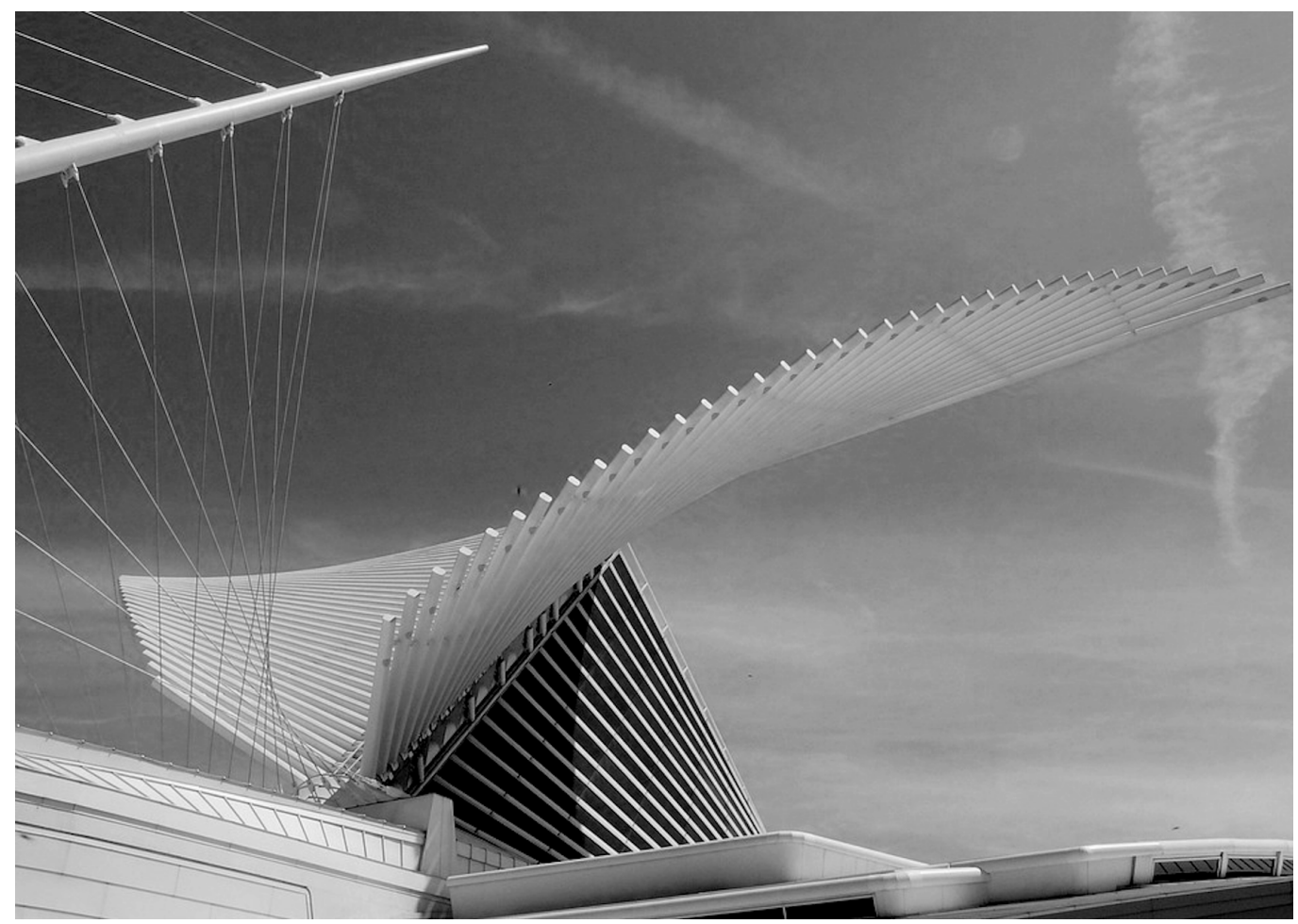


These few references should be read as an opportunity to relaunch a debate on the geometrical reasons of shape, which today we believe to be a fundamental element of critical reflection and a central point of development in architectural research, for its effects on education and the professions. As a means of maintaining attention on this issue, the value of form must be handed down to future generations. We are convinced that the most effective way of transmitting this value is the experimentation through direct fruition of the models that represent it and their mutual relations and transformations. These beliefs are the foundation of ongoing research oriented towards the creation of a museum of shape, conceived as a virtual and physical laboratory in which to explain and experiment, in a dynamic and interactive way, the relationships that link geometry, shape and design.

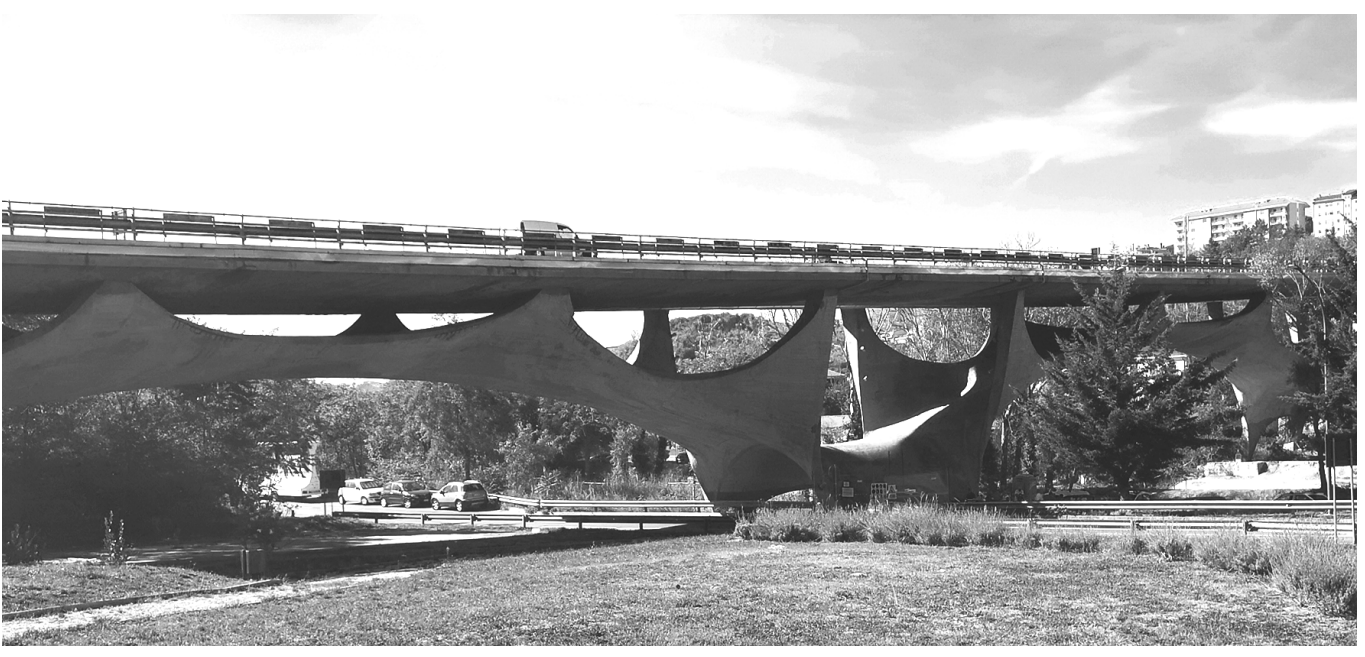

\section{Towards an idea of musealization}

The idea of a space that can make explicit the remarkable properties of lines and surfaces by analyzing how they can be used in the constructed form of architecture, therefore finds its most effective realization in a museum of form. A changing and constantly evolving space defined by a robust laboratory character in which to experiment and verify the specificities of geometric entities, exhibited through physical and virtual models, in a cyclic system that transforms and integrates one into the other.

The link with the collections of mathematical models made in Europe between the second half of the nineteenth century and the early twentieth century is evident. These were the object of a cultural operation of strong impact that involved the greatest scientific minds of the time. Their aim was "to show the remarkable properties regarding the theme of investigative research and to show some of the results progressively achieved in the various areas of 'pure'and 'applied' mathematics: Descriptive and projective geometry, Analytical geometry, Algebraic geometry" [Palladino 2009, p. 3I]. The mathematical models of the numerous collections were made of different types of materials such as plaster, brass, metal wires and, despite their artisan character, they effectively responded to the need to show and demonstrate the remarkable characteristics of the represented entities through an analogical visual language (fig. 6). Thus, an intuitive approach to geometry was favored, which, in accordance with Hilbertian teachings, "led to a clear perception of the considered objects and to a concrete representation of their reciprocal relations" [Hilbert 1932, p.VII].

These forms of the visual communication of mathematics were the starting point for the definition of an expositive idea, articulated around the realization of models. Inserted in a 
museological context, these "scientific objects" which illustrate form, must be offered to the public in such a way as to allow a deep understanding of their nature. In order to facilitate this critical reading, we believe it necessary to revisit the semantic value of these models, which must show not only the ultimate result of their geometric construction but the entire generative process from which they come, their properties and the impact that these properties have had and continue to have in the constructed form. Not this alone however; it is also necessary to redesign, in the manner of a museologist, a system of relationships able to connect the objects exhibited among themselves, to hatch a story-line of the transitions between the one and the other and to establish the modes of interaction between objects and users.

We believe that this system of connections must operate through the visual languages of descriptive geometry, which are not symbolic in nature, but synthetic. These languages, through which the synthetic method investigates and communicates form, are based on the 'constructive' character of this science. Gino Loria, in the early twentieth century, claimed that construction is an existential demonstration of form and, never more than today, in the virtual space of a computer, does this statement appear so topical [Loria 1935, pp. 77-83]. The idea of construction makes its meaning explicit if we intend the geometry of extension as the science that deals in abstract terms with repeatable procedures that can be reproduced in physical reality.

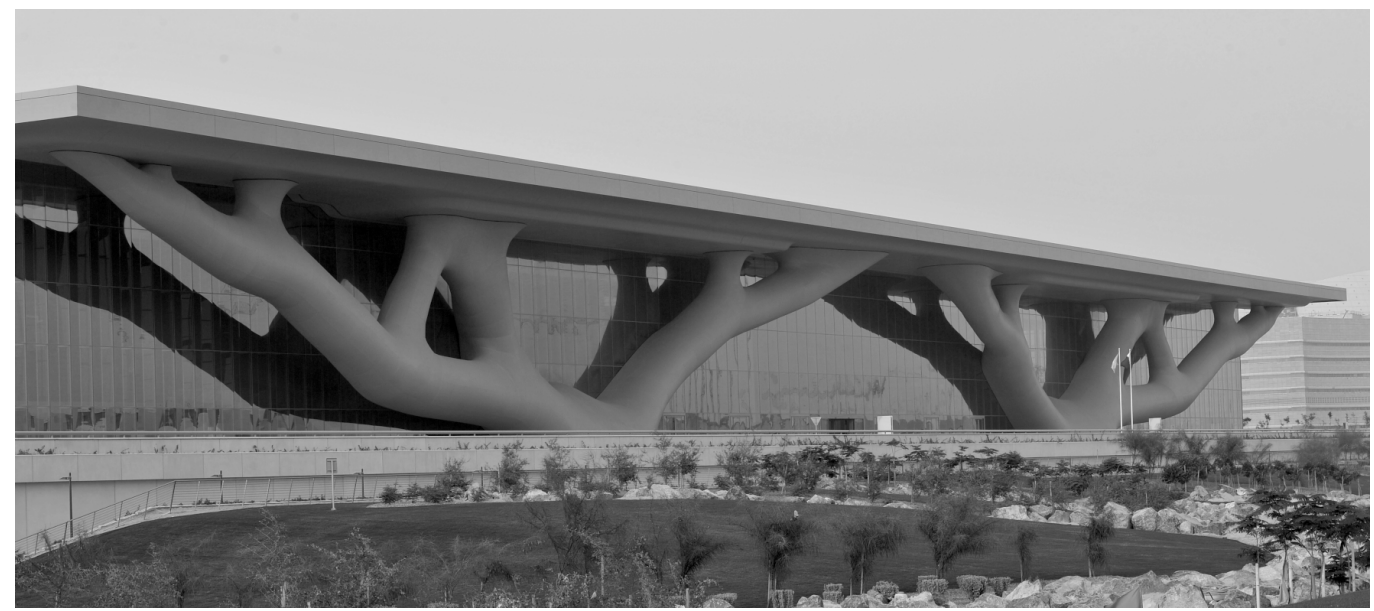

The concept of 'model', in the architectural tradition, expresses a combination of art, science and technology, describing a set of operations representing form in its broadest sense, realized and designed.The model, static in its analogical conception, has changed paradigm with the advent of digital representation. If analogical models, both graphical and physical, communicated one aspect at a time of the represented object, today digital models constitute a platform for dynamic and immersive exploration of form. In fact, the same digital model can describe different aspects, declining from time to time in different ways, to satisfy different purposes. This adaptability is reflected in the digital environment, through static or dynamic modes in the use of form, encouraging immersive exploration and interoperability between different areas of experimentation. At the same time this is reflected in real space, where the model, prototyped, acquires physical form, favoring direct interaction with form. The idea of a model that structures this exhibition space is, therefore, that of a dynamic and mutable 'scientific object' that fits into an organic system of relationships capable of reproducing and making explicit the generative processes.

From this perspective, several prototypical experiences have been carried out, developed in the research and teaching fields, which we consider significant with respect to the classifica- 
Fig. 5. The fiber-reinforced concrete panels of Louis Vuitton Foundation designed by Frank O. Gehry in 2014 .

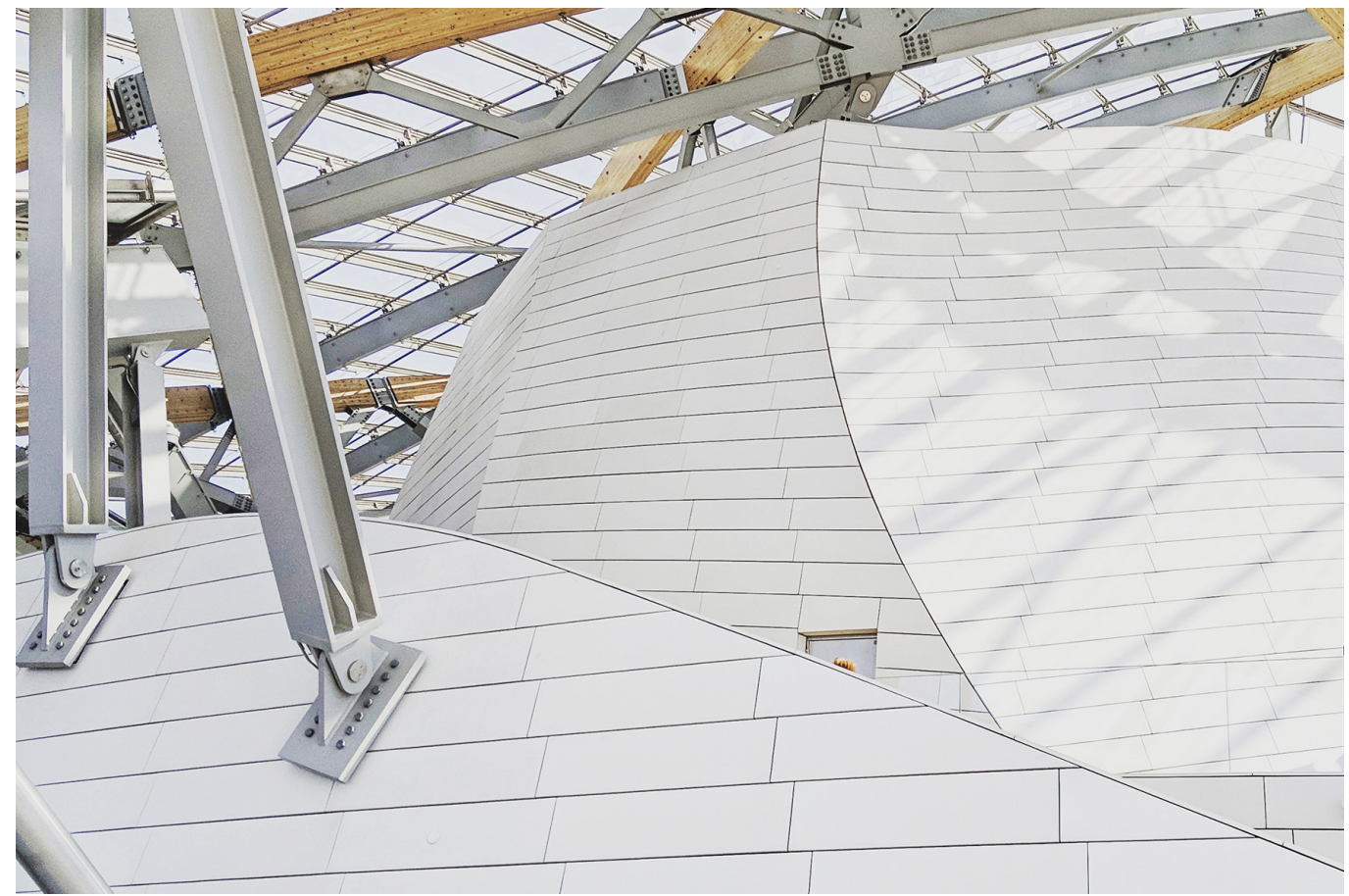

tion of the generative processes mentioned in the previous paragraph. In the case of locus surfaces, for example, geometry intervenes in the conceptual phases of the design process and, since it is a formal matrix, requires a continuous representation of form. If we think about the use of the hyperbolic paraboloid in Felix Candela's projects, we can observe how the properties of this surface, its genesis, its symmetry, its flat sections, are elements that structure the morphology of the project and allow control of its parts [3] (fig. 7). The same goes for Santiago Calatrava's architectures, among which the kinetic ones are of particular interest, where movement strictly depends on the geometric genesis of the surfaces used [4]. In these cases the parametric representation of the project seems the most effective tool to express the kinematics of form (fig. 8). Different is the case of architecture in which geometry intervenes in itinere, and therefore it is the result of some constraint conditions, according to a finding form approach. In these cases the process prevails over the finite form and the representation traces its generative algorithm, as shown in a re-reading of the geometry of the bridge over the Basento in figure 9. In reference to another case exemplifying the modus operandi that supports this idea of musealization, let us consider the case in which geometry intervenes ex post. For this purpose it is particularly interesting to refer
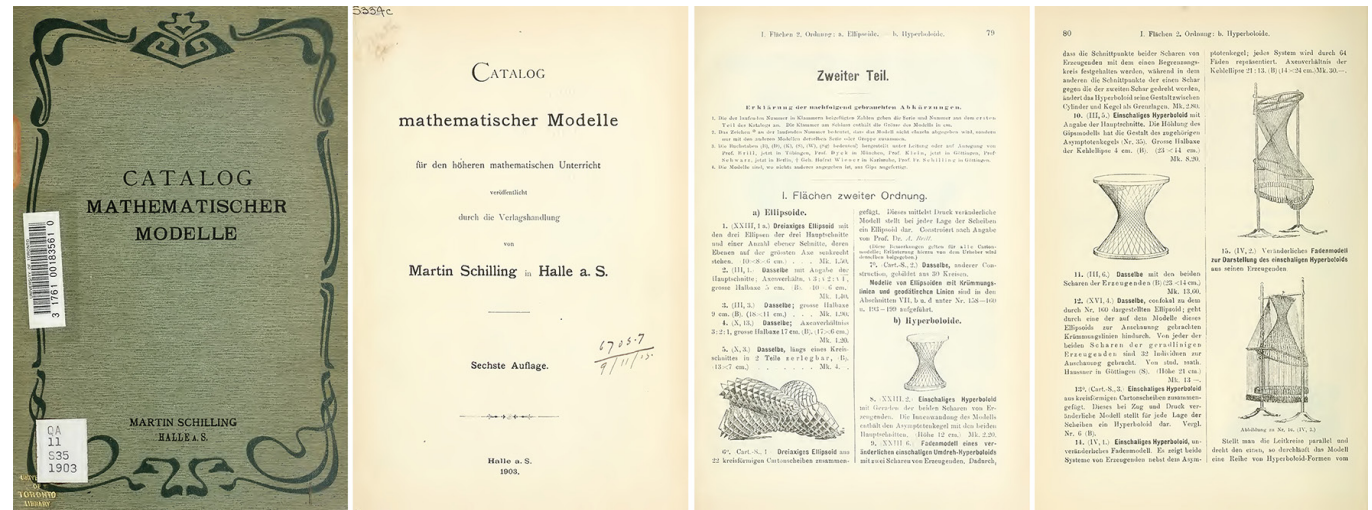

Fig. 6. Martin Shilling's catalogue of mathematilization of geometrical objects (1911). 
Fig. 7. Several groups of Parabolic Hyperboloid in some of Felix Candela's

projects (models by
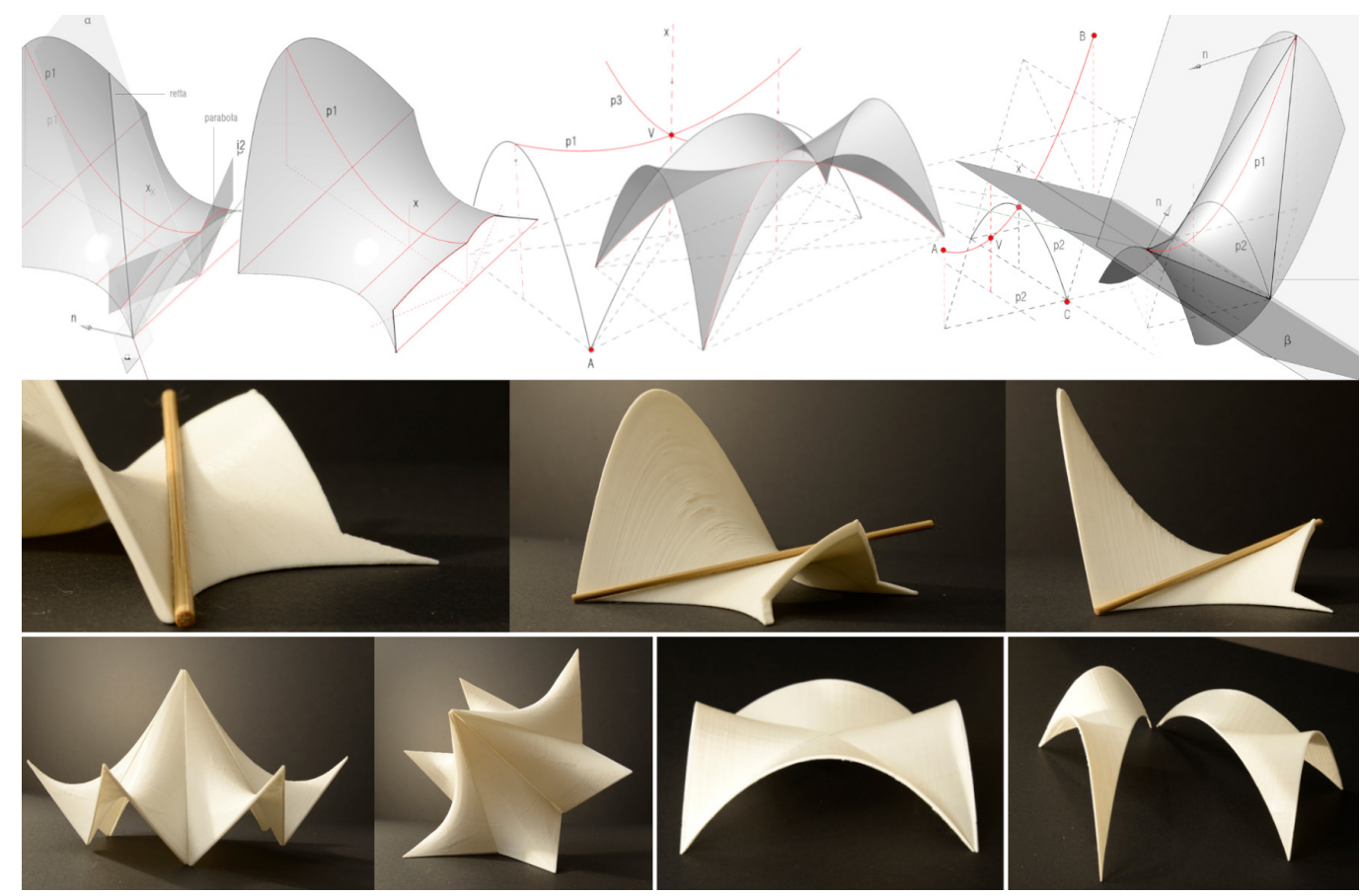

Fig. 8. Parametrical

Models for the re-reading

of kinetics architectures

by Santiago Calatrava

(models by Alessandra

Natale).
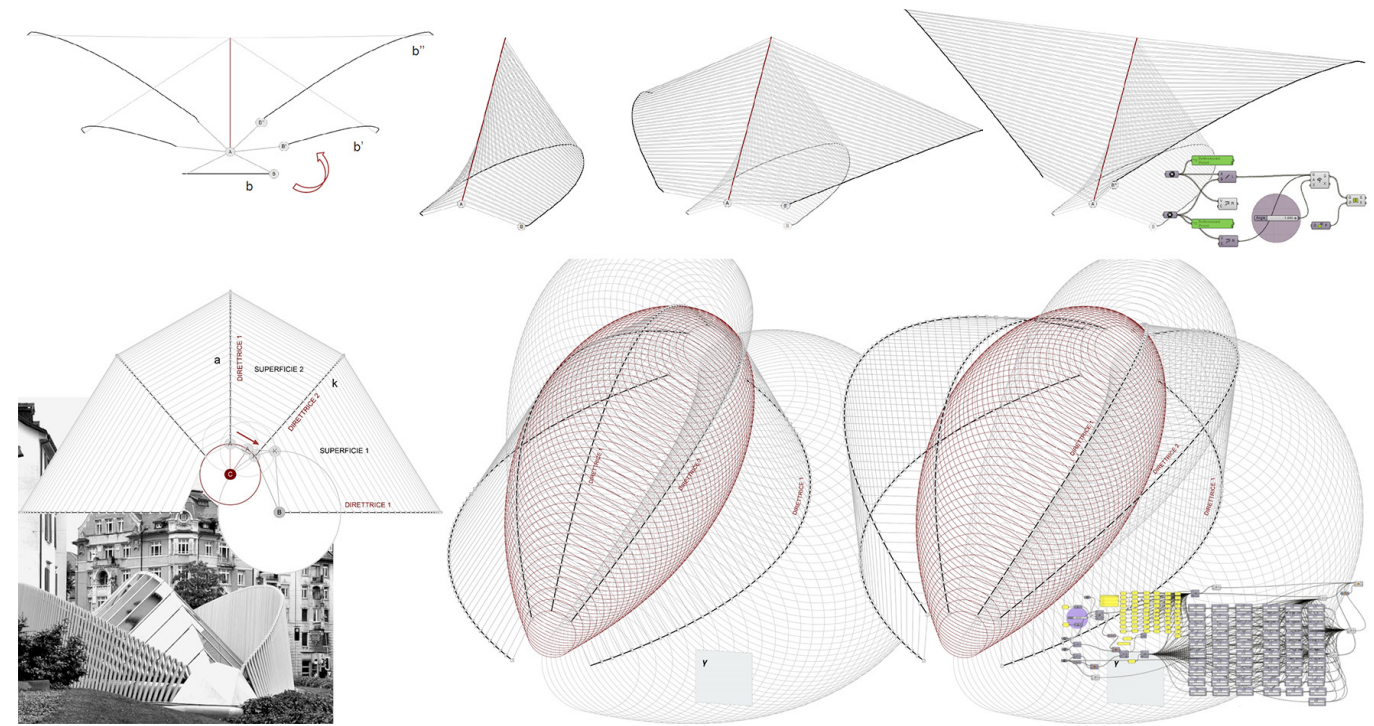
Fig. 9. Finding form process through digital tools for studying catenary structures (above) minimal surfaces (bottom).

Fig. 10. Discretization of free form surface through polyhedral surface

composed by planar quadrilateral elements (PQmesh).
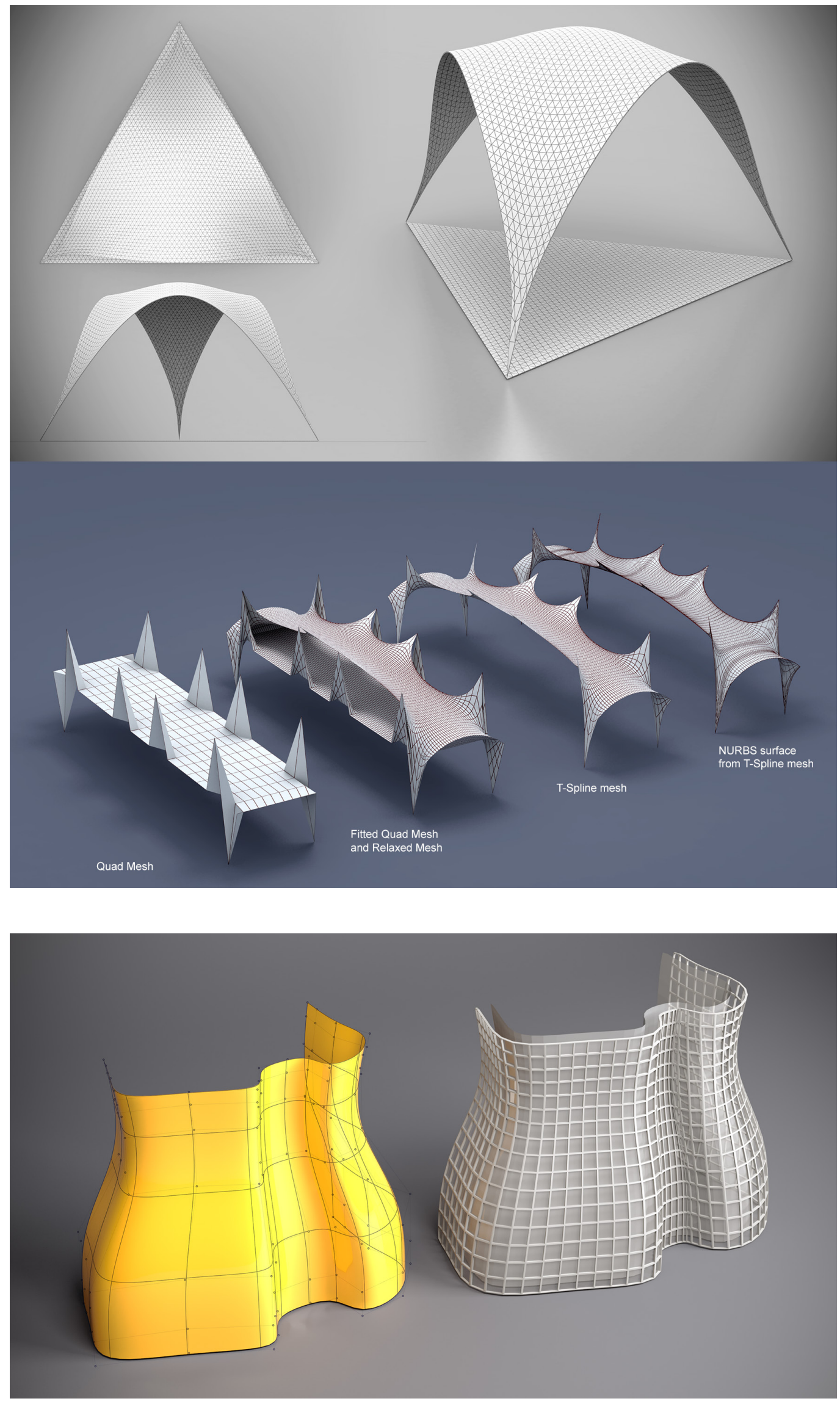
to the experimental architectural applications of the PQ-mesh (Planar quadrilateral mesh) [Pottmann 2007, p. 677] which are derived from the curvature lines of a continuous surface discretizing it into quadrilateral plane elements (fig. I0).

\section{Development prospects}

In 1966 Richard Fleischer's Fantastic Voyage was released on cinema screens. The film tells of an adventurous voyage inside the human body, led by a crew aboard a submarine, both miniaturized. Even today, more than fifty years later, although accustomed to products of the most modern CGI technologies, it is not difficult to understand the communicative impact that those images had on viewers and how this served to make known to a very large and heterogeneous audience, the form that belongs to us but which we ignored. An incredible result, which was not achieved due to the primordial special effects, but rather by soliciting the spectator's dreamlike imagination through the change of scale and the passage between the view from outside to inside.

Precisely in this perceptive duality, characteristic of the passage from small to large scale, as well as from the real to the virtual and again from content to container, we think that the communicative and formative objective of a museum of form can find fulfilment; a space where the experience of knowledge takes place in a continuum between the model of architecture and architecture itself: equally experiential, equally communicative, equally formative (fig. II).

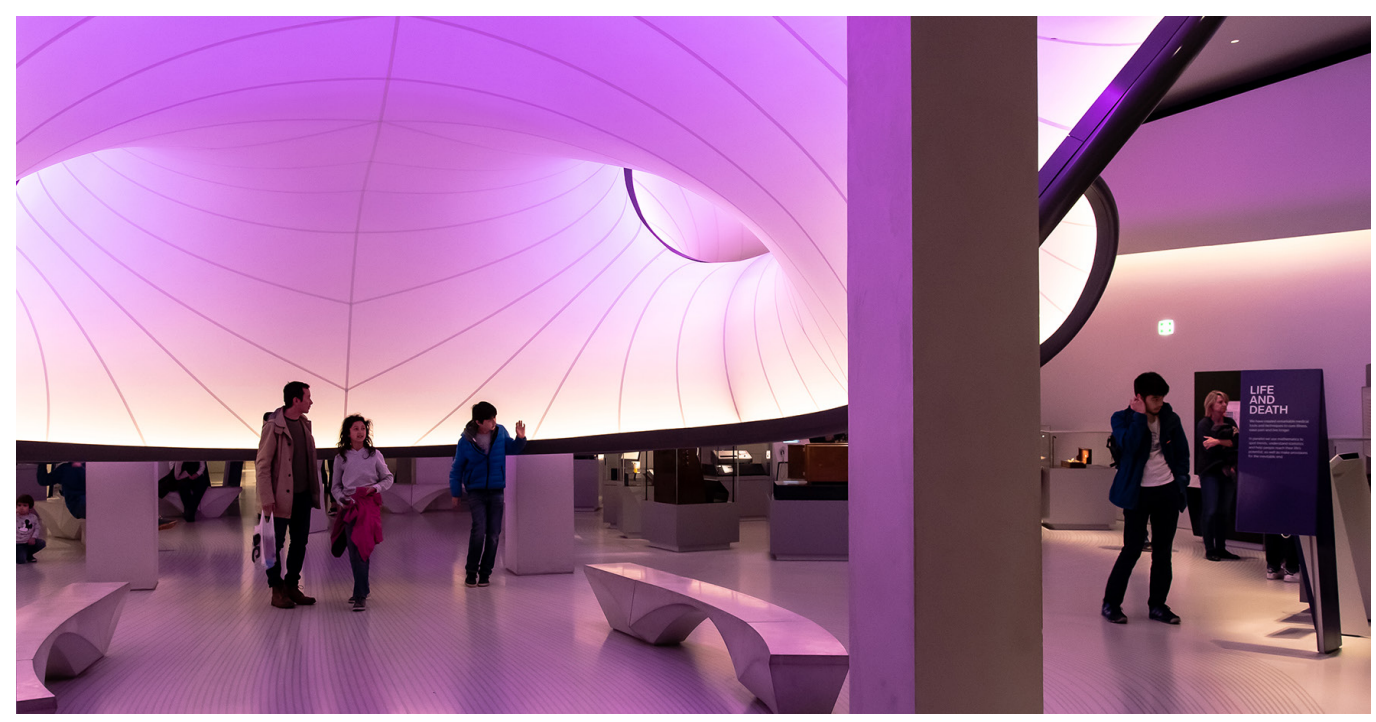

Notes

[I] Just as drawing favors experimentation on shape, likewise it requires increasingly effective and avant-garde instruments of representation for its communication, nourishing a virtuous cycle that has, over time, constantly enriched the repertoire of shape in the art of design.

[2] The Qatar National Convention Center of Isozaki is, together with the project for the TAV station in Florence (2002), among the most significant examples of buildings that use generative algorithms for topological optimization of an evolutionary type, pointing up the potential of the ESO method [Capruso, Martire 20 I5, p. 106].

[3] We observe in particular how different portions of the same surface, sectioned according to sizeable (o considerable) curves, give rise to, in their aggregation a repertoire of morphologically very different works.

[4] Many of Santiago Calatrava's kinetic architectures use ruled surfaces with director plane; the shaft that belong to each of the surfaces that compose the architecture rotate on planes that have the same position as the director planes and describe arcs of circumference during motion. 


\section{References}

Capurso Gianluca, Martire Francesca (2015). "Buongiorno, signori. lo sono un elaboratore ELEA 9000”. Calcolo automatico e progettazione strutturale. In Martire Francesca (a cura di). Storia dell'ingegneria strutturale in Italia - SIXXI 2. Roma: Gangemi Editore, pp. 98-1 I0

Di Palma Wilma (1999). Un Museo della Matematica: Utopia o realtà possibile. In Di Palma Wilma (a cura di). I racconti di Numeria. Guida alle collezioni di modelli matematici del Comune di Roma. Roma: Argos, I0 pp.

Hilbert David, Cohn-Vossen Stefan (1972). Geometria Intuitiva. (Traduzione di Adolfo Verson). Torino: Bollati Boringhieri. (Ed. orig. Anschauliche Geometrie Einfachste Grundbegriffe der Topologie. Berlin: Springer-Verlag, 1932).

Imperiale Alicia (20 18). An 'Other' Aesthetic: Moretti's Parametric Architecture. In LOG, 44, pp. 7I -82.

Loria Gino (1935). Metodi matematici. Milano: Hoepli.

Palladino Nicla, Palladino Franco (2008). I modelli matematici costruiti per l'insegnamento delle matematiche superiori pure e applicate. In Ratio Mathematica, 19, pp. 3 1-88.

Pottmann Helmut et al. (2007). Architectural Geometry. Exton: Bentley Institute Press.

Vaudeville Bernard et al. (2013). How Irregular Geometry and Industrial Process Come Together: A Case Study of the "Fondation Louis Vuitton Pour la Creation", Paris. In Hesselgren Lars et al. (eds.). Advances in Architectural Geometry 20 I 2. Wien: Springer-Verlag, pp. 343

\section{Authors}

Leonardo Baglioni, Sapienza Università di Roma, leonardo.baglioni@uniromal .it

Marta Salvatore, Sapienza Università di Roma, marta.salvatore@uniromal.it.

Graziano Mario Valenti, Sapienza Università di Roma, grazianomario.valenti@uniromal.it

To cite this chapter: Baglioni Leonardo, Salvatore Marta,Valenti Graziano Mario (2020). Verso una musealizzazione della forma/Towards a Musealization of Shape. In Arena A., Arena M., Brandolino R.G., Colistra D., Ginex G., Mediati D., Nucifora S., Raffa P. (a cura di). Connettere. Un disegne per annodare e tessere. Atti del $42^{\circ}$ Convegno Internazionale dei Docenti delle Discipline della Rappresentazione/Connecting. Drawing for weaving relationships. Proceedings of the 42th International Conference of Representation Disciplines Teachers. Milano: FrancoAngeli, pp. 47-66. 